\title{
Etik Kodların Örgütsel Açıdan Değerlendirilmesi
}

\section{Günce DEMIR ${ }^{1}$}

\section{$\ddot{O} z$}

Bu çalışmada bir şirketin 2018 yılında yayınlamış olduğu "Şirket Etik Kodları"nın şirket çalışanları açısından anlaşılırlı̆̆1 ve uygulanışı değerlendirilmiştir. Bu çalışmanın amacı yaşayan ve gelişen bir olgu olarak etik kodların şirketler açısından katkıları ve önemini ortaya koymak ayrıca günümüzde giderek yaygınlık kazanan bir kavram olarak etik kodlar kapsamında hareket eden/ ettiği var sayılan bir firmanın mevcut etik kodları nasıl uyguladığını gözler önüne serilerek benzer firmalara ve diğer potansiyel paydaşlara etik kodları uygulama konusunda rol model anlamında katkı sağlamaktadır. Bu kapsamda çalışma dahilinde bir şirketin 2018 y1lında ilan ettiği on yedi etik kod ilkesinden yola çıkılarak beşli likert tipi ölçek ile bir anket uygulaması yapılmıştır. Google Forms uygulaması aracılı̆̆ı ile yapılan bu ankete 66 şirket çalışanından 61’i katılım göstermiştir. 2018 yılında belirlenen on yedi şirket etik kodunun şirket çalışanları tarafından iki yıl sonra (2020 yılında) nasıl algılandığı ve değerlendirildiğine bakılması hedeflenmektedir.

\section{Anabtar Kelimeler: Etik, Etik kod, Şirket Etik Kodları, Değişim}

\section{Evaluation of Ethical Codes from an Organizational Perspective}

\begin{abstract}
In this study, the understandability and enforcement of Code of Ethics is evaluated through a company's real world experience of their employees. The purpose of this assessment is to reveal the contributions and importance of ethical codes for company as a living and developing phenomenon; and also as a concept to understand how a company acts within the scope of ethical codes, increasingly wide spreading as real life implementations for companies today. At 2018, the company that is the subject of our study stated that it had not included any codes contradicting with their rules and the company culture and existing practices. It has been supported by the top management, doesn't accept exceptions and has applied equally to all employees without discrimination. Seventeen ethical codes determined by the company are discussed within the scope of this study.
\end{abstract}

Key Words: Ethic, Code of ethic, Organizational Code of Ethic, Change

Atıf İçin / Please Cite As:

Demir, G. (2021). Etik kodların örgütsel açıdan değerlendirilmesi. Manas Sosyal Arasstırmalar Dergisi, 10(4), $2314-$ 2332.

Geliş Tarihi / Received Date: 27.03.2021

Kabul Tarihi / Accepted Date: 26.06.2021

\footnotetext{
${ }^{1}$ Dr. - Kırıkkale Üniversitesi Fen Edebiyat Fakültesi Sosyoloji Bölümü, gunceyilmaz@gmail.com

(D) ORCID: 0000-0001-7747-6769
} 


\section{Giriş}

İnsanlık tarihi kadar eski olan etik, ahlak sözcükleri, gündelik yaşamımızda sözlü ve yazılı olarak sıkça karşılaştığımız kelimeler arasında yer almaktadır. Söz konusu sözcükler öncelikle felsefe, sosyoloji, hukuk ve günümüzde de işletme ve teknoloji olmak üzere birçok bilim dalı tarafindan incelenip tartısılmaktadır ve tartışılmaya da devam edilecektir. En basit haliyle etik, insanlar arası ilişkilere ve davranışlara yön veren beşerî davranış kuralları bütünlügüdür. Birey yaşamını bu kurallara göre şekillendirir. Diğer yandan da toplumsal yaşamın, önceden tümüyle bilenebilir ve düzenlenebilir bir yapısı yoktur. İçerisinde belirsizlikleri, öngörülemezlikleri barındıran bir yapısı vardır. İşte bu noktada önceden sınırları belirlenmiş, o yapıya uygun etik kodlarla ihtiyaç duyulur. Etik kodların en büyük özelliği, insanlar tarafindan benimsendikleri ve üst yönetimin de katılımı sağlandığı sürece geçerli olmasıdır. Etik kodlar iyi ve doğru davranışın temeli olarak ele alınırken, şirket etik kodu bir şirketin her anlamda sorumluluklarını en iyi şekilde nasıl yerine getirebileceğini gösteren bir kılavuz gibi değerlendirilmektedir. Öyle ki bu kılavuz, bir şirketin hem kendi içinde hem de şirket dışı ilişkilerinin doğru, verimli ve düzenli işlemesini sağlayacaktır. Ancak etik kodların bir kere oluşturulması yeterli değildir. Değişimin kaçınılmaz olduğu bir düzende şirket etik kodlarının da uygulanışı ve geçerliliğini koruması bağlamında tekrar tekrar değerlendirilmesi gereklidir. Bir diğer deyiş ile etik kodlar1 yaşayan bir süreçtir. Bir şirket etik kodları belirlediğinde bu süreç sona ermez. Yaşanan değişim ve dönüşümler ışı̆̆ında etik kodların yeniden gözden geçirilmesi gerekmektedir. Bu çalışmada amacımız öncelikle etik kod ve şirket etiği hakkında belirli başlıklara değinerek sonrasında organizasyonel açıdan var olan etik kodları değerlendirmektedir.

\section{Etik Kod Nedir?}

Etik kodlar; iyi ve doğru davranışlar için normlar ve değerler koymakta, standartlar belirlemekte, ahlaki davranışları göstermekte ve ikilemler ortaya çıktığında ahlaki kararlar alınmasına yardımcı olmaktadır (Paters ve Gills, 2003, s. 764). Özellikle son yıllarda dünyada ve ülkemizde iş dünyasından medya dünyasına, siyasetten bilime kadar neredeyse her alanda yaşanmaya başlanan ahlaki erozyonun giderek yaygınlaştığına ilişkin görüşlerin sıklıkla dile getiriliyor olması, etik ve etikle ilgili konulara daha fazla önem verilmesine neden olmaktadir. Bunun bir sonucu olarak da hemen hemen her alanda ve her meslekte bir etik kod olușturma çabası dikkat çekmektedir (Yüksel, 2015, s. 11). Tarihsel sürece bakıldığında ahlaki kurallara her zaman ihtiyaç olduğu gözlenmektedir. Yaşadıkları dönemde, yaptıkları görevler hakkındaki tecrübelerinden yola çıkarak bazı düzenlemeler belirleyen Hammurabi ve Hipokrat'tan, en iyi ahlaki davranışın öğütlenmesi şeklindeki nasihatname yöntemini oluşturan İbn-i Haldun'dan bu yana, doğru olanı yapmanın daha kolay ve tercih edilen olacağı düşünülmektedir. Bunun bir sonucu olarak yazılı hale getirilip sistemleştirilen davranış standartları, kabul edilir davranışlarla minimum beklentileri açıklamak ve aydınlatmak amacıyla etik davranmayı sağlayan kurallar, günümüzde etik davranış kodları "ethical code of conducts" adı altında yazılı hale getirilip sistemleștirilmiştir (Signh, 2017, s. 138). Zaman içinde de geliştirilerek çeşitli mevzuatlarla da desteklenmektedir. Bu çalışmalardaki ortak amaç ise; etik alt yapıların incelenerek etik ilkeler konusunda uluslararası standartları ortaya koymak ve her meslekte etik anlayışının benimsenmesine yardımcı olmaktır. Bu kapsamda etik kod; literatürde son yıllarda en sık rastlanan terimlerden biri olmakla birlikte, ülkemizde çokça karşımıza çıkan ve bir o kadar da farklı ve yanlş̧ tanımlamalarla ele alınan bir kavramdır (Yilmaz, 2007, s. 41).

Bazı yazarlar tarafindan etik kod kavramı, bireylerin ve diğerlerinin zihninde anlamlar meydana getirmek için kullanılan simgelerin, sembollerin sistematik düzenlenmiş şekli olarak tanımlarken (Harlak, 2003, s. 19, Paters ve Gills, 2003, s. 764) ise etik kodları; "Ahlâkî uyum politikalarını içeren yani ahlâkî standartlar, temel değerler, prensipler, organizasyonun etiksel uyumunu ifade eden ve iş görenlerin davranışlarına veya organizasyonun tümüne yol göstermesi amacıyla oluşturulan resmi ve yazılı dokümanlar" olarak tanımlanmaktadır. Ancak literatür incelendiğinde, özellikle bazı meslekler için, mesleki faaliyetleri yöneten yazılı olmayan gizli ve/veya açık, söz konusu meslek için yeterli davranış standartlarını oluşturan kuralların mevcut olduğu görülmektedir. Muhasebe Meslek Standartları bu belirlenmiş mesleki davranış standardı oluşturmaya yönelik kurallara güzel bir örnektir. Kuçuradi (2006) gibi bazı yazarlar, etik kavramını davranış standartları olarak ele almaktadır. Bu noktadan hareketle etik, bahsi geçen eylem alanını açıklayan kavramın adını ön isim olarak alır ve o kavramın etiği olarak açıklanır. Örneğin tıbbi etik, bioetik, bilim etiği, basın etiği günümüzde sıkça kullanılan kavramlar olarak karşımıza çıkmaktadır. Etiği bu anlamda kullandığımızda meslek sayısı kadar etik koddan bahsetmek mümkündür. Bu etik kodlar uygulamada, o eylem alanında faaliyet gösteren insan gruplarının davranış ilkeleri olarak düzenlendiğinde ya da diğer bir ifadeyle sadece o kavramın altında toplanan uğraşı alanlarını ilgilendirecek 
şekilde düzenlendiğinde "meslek etiği" olarak da adlandırılabilmektedir. Ancak yine Kuçuradi’ye göre (2006); değişik meslek etiklerinin veya mesleki etik kodlarının yapmaya çalıştıkları şey özel türden normlardır. Ancak bu normlarda bulunması gereken en önemli koşul, ilgili meslek sahiplerinin, kişilerin sahip oldukları dünya görüşlerinden, kültürlerinden, ideolojilerinden, dinlerinden bağımsız olarak uygulamaları beklenen kurallardır. Ancak yazılı olmayan bu normlara veya norm sistemlerine "ahlak

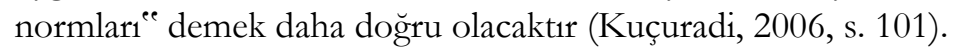

\section{Şirket Etik Kodları Neden Gereklidir?}

Yukarıda değinilen "meslek etiği” kavramının ötesinde, özellikle serbest piyasa ekonomisinin etkisi ile pazarda ve sektörlerde karşımıza çıkan pek çok firma, kurum, kuruluş ile meslek etiğinin ötesinde "şirket etiği", "iş yeri etiği" gibi yaklaşımlarında ön planı çıktığı gözlenmektedir. Bu durum tıpk1 meslek etiği kavramında değinildiği gibi belirli davranış standartları belirleme ve böylece düzen ve istikrarın sağlanması açısından oldukça gerekli bir uğraş olarak düşünülmektedir. Bu nedenledir ki "etik" kavramına ve özellikle "is, etiğì" konusunda işletmelerin etik kod geliştirme çalışmalarına, son yıllarda büyük ilgi gösterilmektedir. Etik kodların şirketler için önemi sadece iç ilişkilerin düzenlenmesi açısından değil, etik dışı davranışların firma için yaratabileceği temsil sorunlarından, itibarına, üretkenliğinden, kar oranında yükseliş ya da düşüsslere kadar pek çok farklı açıdan etkiye sahiptir (Signh ve Prasad, 2017, s. 138).

Günümüzde yaygin olarak kullanılmaya başlayan etik ve etik ile ilgili diğer kavramlar, Türkçe’ye seksenli yılların sonlarında girmeye başlamışır. Ayrıca "etik" kavramın kendi içinde "ahlak", "norm", "değer" gibi kavramlarla dirsek teması olması kavramın hem literatürde hem de günlük hayattaki kullanımlarında farklı veya hatalı değerlendirmelere yol açmaktadır. Örneğin Akademisyen Harun Tepe'nin 1998 yılında akademik bir dergiye gönderdiği "Etik ve Meta-etik" başlıklı yazısına editörün verdiği cevapta, etik sözcüğü editöre anlamsı göründüğü için kelimenin "etnik" olarak düzeltilmesi istendiğinden bahsedilmektedir. Yine Türkiye Etik Değerler Merkezi (TEDMER) tarafindan 2002'de yapılan bir araştırmada "iş etiği kavramını duydunuz mu?" sorusuna verilen cevapların \%36 sının "hayır" olması, bu kavramın ülkemizde 2000'lerin başlarında henüz yeterince bilinmediğini göstermektedir. Türkiye açısından konunun gündeme getirilme ve tartışılmasının 2000’lerin ortalarında hız kazandığ1 gözlenmiştir. Uygulamada, ulusal pazarı koruyucu önlemler özelliği taşıyan gümrük duvarları ve kotaların kaldırılması, uluslararası standartlara uyulması gibi konuların ilgi alanı içinde olması nedeniyle "etik" ve "iş etiği" kavramı kendinden daha çok söz ettirir olmuştur. Bunun nedeni olarak da iş etiğinden söz etmek, günümüzde de popüler olan doğaya karşı saygılı olmak, hakça davranmak ve yapılan haksızlıklara karşı çıkmak gibi anlamları içinde barındırdığı düşüncesidir (Torlak, 2006, s. 106). Bunun yanı sıra, tüketicilerin işletme hakkında olumsuz bir ahlaki ününün ortaya çıtı̆ğı durumlarda, işletmenin ürünlerinin güvenliği konusunda da şüphe oluşturmaktadır (Özdoğan, 2007, s. 112). Bu şüpheleri ortadan kaldırılması da ancak iş etiğinin kurumsallaşması ile mümkün olabilir. İş ahlakının kurumsallaşmasını sağlayan en önemli faktör ise tepe yöneticilerinin tutum ve davranışlanıdır. Tepe yönetimi bir işletmenin ahlaki veya ahlaki olmayan faaliyetlerde bulunmasında belirleyici konumdadır (Bayrak Kök, 2006, s. 62). Benzer bir durum, Baumhart'in 1968'de 100 'den fazla is, insanı üzerinde yapmış, olduğu bir çalışmada görülmüştür. Araştırmaya katılan is, insanlarına "etik sizin için ne anlamına geliyor?" sorusu yöneltilmiştir. Soruya verilen bazı cevaplar şu şekildedir, "Ne demek olduğunu bilmiyorum.", "Hislerimin bana doğrudur dediği şeydir.", "Ahlaki standartlardır.", "İnsanın kişisel veya sosyal refahı için belirlenmiş, standartlardır.", "Doğru olduğuna inandığımız şeylerdir." şeklinde olmuştur. Aslında bu cevaplar etik ile ilgili olsa da etiği tanımlamakta yetersiz kalmaktadır (Tevruz, 2007, s. 2). Etik kod kavramı özellikle organizasyonlar açısından önemlidir çünkü günümüzde gelişen teknolojiler ve telekomünikasyon araçlarının yaygınlığı ve becerilerindeki artış ile etik olmayan davranışları kantllayacak çok sayıda veriye kolaylıkla erişilmesi mümkündür.

Rekabetin hızla yaşandığı günümüz iş dünyasında işletmeler pazar paylarını korumak ve sürekliliği sağlamak için farklı yöntem ve teknikler uygulamaktadırlar. Bu yöntemlerden birisi de müşteri güvenilirliğini ve sürekliliğini sağlamaya yardımcı olan etik kod kullanımıdır. Etik kodlar diğer yandan da hem iç hem de dış müşterinin tatminini sağlamaya yönelik ilkeleri de içinde barındırmaktadır. Bu ilkeler işletmede kurumsallı̆̆ın sağlanmasında önemli katkılar sağlamayı ve iş yaşamında tarafların etik çıkmazlarla karşı karşıya kalmalarının da önüne geçecektir. Etik kodlar, mesleklerin ve kurumların yapısallaşmasının temellerindendir. Etik kodlar, kurumların faaliyet alanlarına özgü değer ve ilkeler doğrultusunda çalışanlara yol göstermektedir. Ancak tek başına değer ve ilkelerin belirlenmesi ve belgelerin hazırlanması yeterli olmayacaktır. Örneğin bu konuda çalışan araştırmacılar; etik kodların yapılacak işlerde saptanan standartlar 
olarak tanımlamaktadır. Ayrıca etik kodların kabul edilebilir davranışların minimum özelliklerini ortaya koyduğunu belirtmektedir (Öztürk, 2001, s. 9). Ersel'e göre ise etik kodlar, kurallar belirleme çabasıdır. Kuralların belli olması, oyuncuların seçeneklerini sınırlamaktadır. Bu durumda oyuncunun davranışları kestirilebilir hale gelmektedir (Ersel, 1998, s. 14- 15). Başka bir tanıma göre ise etik kodlar, genel veya özel, düşünsel veya hayali, zorlayıcı veya yasal nitelikli, duvarda asılı 10 altın kural listesi veya eğitim ve öğretim karmaşık sisteminin, uygulamalı ve sürekli revizyonun bir parçası şeklindedir (Plant, 2001, s. 221).

$\mathrm{Bu}$ tanımlamaların ortak noktası, etik kodların, belirsiz ve karmaşık durumlarda karar vermeyi kolaylaştırmak amacıyla geliştirilen yazılı veya yazılı olmayan davranış kalıpları olmasıdır. Diğer bir ifadeyle etik kodlar, çalışma hayatında yer alan herkesin ahlaki çıkmazla karşılaştı̆̆ında hareket yönünü belirleyen bir pusula vazifesi görmektedir.

Öte yandan etik kodlar, yaşamla da iç içedir. Ancak bu kodlar; her yerde her meslek grubu için aynı şekilde karşımıza çıkmayabilir. Çünkü kodların içerikleri, meslekten mesleğe değişebildiği gibi, endüstriler için bile değişebilmektedir. Bu farkl1ılklar nedeniyle kusursuz -evrensel ve sarsılmaz temellere sahip etik kodlar hazırlamak mümkün değildir (Bauman, 1998, s. 20).

Merkezi Londra'da bulunan "Institute of Business Ethics" yaptı̆̆ değişik çalışmalara dayanarak, yalnızca etik kodların oluşturulmasının yeterli olmayacağını belirtmektedir. Çalışanların özellikle karşılaşabilecekleri etik; ikilemlere açıklık getirmenin gerekliliğini belirtmektedir. Ayrıca etik kodlar çalışanlara duyurulduktan sonra da izlenmesinin gerekliliği vurgulanmaktadır (Svensson, 2004, s.180). Özetle etik kodların önemine yapılan vurgulamaya karşın "Etik bir koda sahip olmak her zaman tüm sorunları çözer" iddiasında bulunmak da doğru değildir (Russ- Eft ve Hatcher, 2003, s. 304). Çünkü etik kodların etkinliğini arttırabilmek için çalışanların ve yöneticilerin bu konuda sürekli olarak bilinçli olması gerekmektedir. Programlı olarak etik konusunda eğitim çalısmaları yapılmalıdır. Ayrıca bu çabaların performans değerlendirmesi yapılarak işletmelerin ihtiyaç ve eksiklerinin belirlenmesinde etki eden faktörler tespit edilmelidir.

Şirket etik kodlarının geliştirilmesi şirketin her anlamda sorumluluklarını en iyi şekilde nasıl yerine getirebileceğini ortaya koymaktadır. Bir şirketin hem topluma hem şirket çalışanlarına hem paydaşlarına hem hissedarlarına, hem müşterilerine, hem iş ortaklarına, hem de rakip firmalarına karşı sorumlulukları vardır. Etik kodların geliştirilmesi bu sorumlulukların layıkıyla yerine getirilmesi için önemli bir adımdır. Şirket etik kodlarının geliştirilmesi ile şirketlerin faaliyetlerini taraflara karşı doğru adımların atılması için temel dayanağ1 sunmaktadır. 2014 yllında Rotterdam School of Management ve Erasmus Üniversitesi iş birliği ile dünyanın en büyük şirketlerini oluşturan "Fortune Global 200"ün etik kodlan üzerine bir araştırma yürütülmüştür. Araştırma sonucunda, etik kod konusunda en fazla atıf yapılan 10 temel değer belirlenmiştir (https://home.kpmg/tr/tr/home/gorusler/2017/03/sirketlerin-olmazsa-olmazi-etikkod.html). Tablo 1 de bu 10 temel değerler belirtilmiştir.

Tablo 1. Temel Etik Değerler

\begin{tabular}{cl}
\hline Sira & Temel değer \\
\hline 1. & Doğruluk \\
2. & Saygi \\
3. & Dürüstlük \\
4. & Sorumluluk \\
5. & Güven \\
6. & Müşteri odaklilık \\
7. & Performans \\
8. & İetişime açıklık \\
9. & Takım çalışmasi $/$ iş birliği \\
10. & İnovasyon \\
\hline
\end{tabular}

Yukarıda yer alan tabloda da açık şekilde görüldüğü üzere doğruluk, sayg1 ve dürüstlük en fazla atıf yapılan üç temel değer olarak karşımıza çıkmaktadır. Belirtilen diğer 10 maddeden yola çıktı̆ı̆ıızda şirket etik kodların belirlenmesi, etik beklentileri artırmak, bu konudaki söylemleri yasallaştırmak, etiksel karar vermeyi teşvik etmek ve uygulamalarda yetkinin kötüye kullanımını engellemek için en temel amaçtır.

Öte yandan bazı araştırmacılar etik kodların başkalarının eylemlerini sınırlamak için tasarlandığına inanırken, bazı araştırmacılara göre de kodlar aslında kurum üyelerini daha güvenli ve etkili kararlar vermek için özgürleştirmekte ve güçlendirme olanağı sağlamaktadır. Dolayısıyla etik kodlar yüksek standartlı davranışların önünü açmakta (Peppas, 2002, s. 45) böylelikle iş yaşamındaki belirsizlikleri azaltmakta, daha 
az kaynak ve zaman harcayan, dolayısıyla daha etkin bir mekanizmanın oluşmasını sağlamaktadır (Ersel, 1998, s. 19). Diğer bir deyişle; iş hayatındaki yönetsel faaliyetlerin anahtar öğelerinden birisinin etik kodlar olduğu söylenebilir (Valentine ve Fleischman, 2002, s. 301). Etik kodlar yöneticilere iyi işler yapmak ve kötü işlerden uzak durmak için bir pusula görevini üstlenmektedir. Ayrıca değerler arasında bir çatışma olduğu zaman karar alıcılara yol gösterici bir rol üstlenmektedirler (Öztürk, 1998, s. 22). Yine etik kodların, örgütlerin etiksel karar vermek için bu gerekliliğin farkında olup olmadıklarının ve bu gerekliliğin taahhüt edilip edilmediğinin araştırılmasında somut bir yol gösterici olduğu da düşünülmektedir. Bu nedenle yönetim kuramları ve yöneticiler için stratejik önem taşıyan kavramlardan biridir. Bu bağlamda kodların yönetimsel faaliyetlere adaptasyonunun güçlü bir şekilde desteklenmesi oldukça önemlidir.

\section{Şirket Etik Kodları Nasıl Olmalıdır?}

Daha önce de söz edildiği gibi etik kodların oluşturulmasındaki ana amaç; etik davranışın Özendirilmesi ve etik dışı davranışların önlenmesidir. Bunun dışında çalışanların davranışlarının değerlendirilmesi için etik kodların oluşturulması, karar alma sürecinde örgüt yararı ile bireysel çıkar arasındaki tercih sırasında bir güçlükle karşılaşılması halinde yararlanabileceği bir rehberin bulunmasını sağlamaktır (Doğan, 2009, s.179). Bir diğer amaç ise, örgütsel faaliyetlerin sonuçları ile ilgili hak ve sorumlulukların ortaya konulması, çalışanların örgütsel ya da mesleki olarak amaçladığ1 hakkaniyet, tarafsızlık gibi temel ilkelerin oluşturulmasıdır. Bununla birlikte yine etik kuralları ihlal etmesi durumunda uygulanacak yaptırımların belirlenmesi de etik kodlar kapsamı içerisinde yer almaktadır (Çabuk ve Şengül, 2005, s. 171). Şirket etik kodları geliştirilirken günlük karar alma süreçleri ve işleyiş şekillerinin göz önünde tutulması oldukça önemlidir. Türk Sanayicileri ve İşinsanları Derneği tarafindan hazırlanan etik kodlar şu özellikleri kapsamalıdır (TÜSİAD, 2005, s. 23-24):

- Yalın bir dil kullanılarak hazırlanmalıdır, amaçlar açıkça ifade edilmelidir.

- Taslaklarla ilgili yorumlar dikkatlice incelenmeli, diğer grupların talep ve eleştirileri dikkate alınmalidir,

- Eğitim, denetim ve yaptırım mekanizmalarıyla desteklenmelidir,

- Etik ikilemleri çözmek için çatışma ve karmaşaya yol açmayacak olumlu bir yaklaşım izlenmelidir.

- Davranış kuralları, tüm toplumsal alanlarda iyi yönetimin, saydamlığın, dürüstlüğün ve etik ilkelerin uygulanmasını desteklemek düşüncesi ile hazırlanmalıdır.

- Hazırlanma ve güncelleştirilme sürecinde katılım sağlanmalıdır,

- Adalet ilkeleri ile kural uygulayıcılarının dürüstlüğü ve etkinliğini sağlamak esas olmalıdır.

- Kurallar gerektiğinde toplumsal değişimlere ayak uyduracak oranda esnek ve yeniden düzenlemeye açık olmalıdırlar.

- Kuralların hazırlanması ve geliştirilmesinde örgüt üyelerinin görüşleri mutlaka alınmalıdır.

Şirket etik kodu geliştirirken; şirketin kültürü, ihtiyaçları, politika ve prosedürleri incelenmeli, anketler, süreç sahipleri ile görüşmeler ve odak grup çalışmaları yapılmalıdır. Kodun yazımı için ihtiyaç duyulan bilgileri topladıktan sonra, şirketin değerleri, uygulamaları ve sektör standartları ile uyumlu olacak bir etik kod taslağı hazırlanmalıdır. Hazırlanan bu taslak, bir yandan üst yönetimle paylaşılırken bir yandan da saha çalışmaları ile test edilmeli ve gerekli düzeltme ve değişiklikler yapmalıdır. Etik kod son haline geldikten sonra mutlaka şirketin hukuk danışmanı tarafından da incelenmelidir. Son haline gelen etik kod üst yönetimin onayına sunulmalıdır. Etik kodun üst yönetim tarafından onaylanmasından sonra kodun ilgili taraflara duyurulması ve içselleştirilmesi için iletişim planı ve eğitim stratejisi belirlenmelidir (Signh ve Prasad, 2017, s. 139-140). Ancak unutulmamalıdır ki, etik kod yaşayan bir süreçtir bir diğer deyişle bir kere yazıldıktan sonra tamamlanmış olmaz, sürekli gözden geçirilerek güncel kalmasına çalışılmalıdır. 
Tablo 2. Sirket Etik. Kodlar

Şirket çalışanları yasalara daima uyarlar.

Şirket çalışanları temel ahlaki ve insani değerler çerçevesinde görevlerini yerine getirirler.

Şirket çalısanları tüm ilişkilerinde karşılıklı yarar sağlamak amacıyla hakkaniyetli, iyi niyetli, anlayışılı ve saygıılı davranırlar.

Şirket çalışanları her ne amaçla olursa olsun kişi ve kuruluşlardan hiçbir şekilde haksız kazanç sağlamazlar.

Şirket çalışanları şirket içerisinde çıkar çatışmasına girmezler.

Şirket çalışanları iş yerinde statüyü, bireysel gücü (unvan, fiziksel, kişisel, yaş) ya da kolektif gücü (sayı fazlalı̆̆ından kaynaklanan güç) kötüye kullanmazlar.

Şirket çalışanları belirlenen iş etiği kuralları ve uygulama prensiplerine uygun olarak hareket ederler, bu kapsamda diğer çalışanların işlerini gereği gibi yerine getirmelerini engel olacak davranışlarda bulunmazlar ve iş ahengini bozmazlar.

Şirket çalışanları unvan ve yetkiden faydalanarak, kendisi, yakınları veya üçüncü kişiler lehine haksız menfaat sağlamazlar.

Şirket çalışanları ticari ilişki içinde bulunulan bir başka şirkette yakınlarının pay veya maddi menfaat sahibi olmasının öğrenilmesi durumunda üst amirine bilgi verirler.

Şirket çalışanları yeni geliştirilen ürün, süreç ve yazılımların fikri mülkiyet haklarını teminat altına alabilmek için yasal olarak ișlemlerin zamanında başlatılmasını ve tamamlanmasını sağlamak, bu tür buluş ve bilgilerin yazılı onay alınmaksızın üçüncü kişilerle paylaşılmasını önlerler.

Şirket çalışanları açıkça yetkilendirilmedikçe şirketi taahhüt altında bırakacak bir davranışta, beyanda ya da yazışmada bulunmazlar.

Şirket çalışanları şirketin gizlilik, bütünlük ve erişilebilirlik politikasını gözeterek, tüm maddi ve gayri maddi varlıklarına şahsi malı gibi özen göstermek, bunları olası kayıp, zarar, yanlış kullanım, suiistimal, hırsızlık ve sabotajlara karşı korurlar.

Şirket çalışanları topluluğa ait her türlü fikri ve sınai mülkiyet haklarına ilişkin gizli bilgilerin üçüncü kişiler ile paylaşılmasının gerektiği durumlarda haklarının korunması için gerekli tedbirleri ilgili prosedürlere uygun olarak alırlar.

Şirket çalışanları tüm kayıtların yasal süresinde sağlıklı bir şekilde tutulmasını ve arşivlenmesini sağlarlar.

Şirket çalışanları üçüncü kişilerden gelen şirket için gizli kategorisine giren bilgi taleplerini, üst yönetim onayı olmadan cevaplamazlar.

Şirket çalışanları şirketin açıkladığı beyan ve sunduğu raporların gerçeğe uygun olması için gerekli şeffaflığı ve titizliği gösterirler.

Șirket çalıșanları olası terör, doğal afet ve art niyetli girișimlere karșı șirket çalıșanlarını, bilgi ve bilgi sistemlerini ve idari tesislerin korunması için gerekli tedbirleri almak ve iletişimini sağlarlar.

Yukarıda yer alan Tablo-2'de araştırmamıza konu olan şirketin 2018 yllında ilan etmiş olduğu şirket etik kodlanı liste halinde yer almaktadır. Belirtilen etik kodlara bakıldığında şirketin örgüt iklimi açısından ne kadar bir arada olmaya ve ayrımcılıktan kaçınmaya çalışmaya önem verdiği, firma çalışanlarının adil ve barış içerisinde bir ortamda çalışmaları için gerekli düzenlemelerin yapılmaya çalışıldığı görülmektedir. Ayrıca firmanın bilgi güvenliği ve müşteriler, paydaşlar gibi taraflarla olan ilişkilerin açıklığ konusunda da gösterdiği titizlik ve özen geliştirilen etik kodlar ile belirtilmektedir.

\section{Yöntem}

Bu çalışma 2018 yllında çalışmaya konu olan şirketin belirlediği etik kodların çalışanlar tarafindan nasıl algılandıklarını belirlemek amacı ile yapılmıştır. Şirketin, isim belirtilmeksizin, bazı temel özelliklerine değinmenin çalışmanın kapsamın anlaşılması ve başka benzer firmalarda yapılacak çalışmalara örnek olması açısından faydalı olacağı düşünülmektedir. 2012 yılında biyometrik güvenlik, kriminal analiz, vatandaş ve göçmen yönetimi teknolojileri geliştirmek üzere hizmet vermeye başlayan firma, 2019 yllinda halka arz olmuş ve 66 çalışan ile birlikte halka açık anonim şirket olarak bugün yapay zekâ, makine öğrenmesi, 
robotik, artırılmış ve genişletilmiş gerçeklik, bilgisayar görüsü, bulut bilişimi gibi alanlarda çalışmalarına devam etmektedir. Firmanın Ankara ili, Çankaya ilçesinde 41 AR-GE personeli ile çalışılan bir AR-GE binası ve idari faaliyetler için bir ofisi bulunmaktadır.

Yukarıda bazı özelliklerine yer verdiğimiz firmanın örnek seçilmesinin en önemli nedeni, 2018 yllı itibari ile etik kodlar hazırlamış ve etik davranış değerleri üzerinden şirket etik politikası yayınlamış olmasıdır. Firmanın 2019 yılında halka arz olması ile şirket içi etik kodların uygulanması ve etik kodlara verilen değer daha da ön plana çıkmışır. Bu noktadan hareketle yaşayan bir olgu olarak ele aldığımız etik kod kavramının şirket içindeki önem ve değerinin belirlenmesi oldukça faydalı olacaktır. Çalışmaya konu olan firmada toplam 66 kişi çalışmaktadır. Çalışanlara, firma yetkilileri tarafindan 2018 yılında oluşturulmuş olan "XXX Çalışanlarının Uyması Gereken Etik Kodlar" temel alınarak hazırlanmış olan anket formu gönderilmiştir. Çalışma belirli bir firmaya yapılmasından dolayı başka araştırmalardaki ölçeklerden yararlanılmamıştır. Firma tarafindan hazırlanmış olan etik kodlar listelenerek şirket çalışanlarının bu etik kodları anket formu üzerinden değerlendirmeleri istenmiştir. $\mathrm{Bu}$ anket formu kapsamında çalışanların firmada çalışmakta olan personelin belirtilen etik kodlara ne oranda uyduklarını likert tipi ölçek üzerinden değerlendirmeleri ve etik kodlara uygun davranılıp davranılmadığ üzerinden etik kodların geçerliliğinin belirlenmesi amaçlanmıştır. Likert tipi ölçek 1932 y1lında Thurstone ölçeğinin basitleştirilmesi ile Rensis Likert tarafindan geliştirilmiştir. Likert tipi ölçeğin amacı konu hakkında tutum veya görüşleri belirten ifadeler oluşturularak bu ifadelere katıllım düzeylerinin belirlenmesidir. Likert tipi ölçekde ifadelere katıllım düzeyini belirlenmek için iki aşırı uç arasında yer alan birden çok seçenek sunulmaktadır. Bu seçenekler derecelerine göre sayısal verilerle ifade edilerek kodlanmaktadır. Böylece nitel veri nicel veriye dönüşerek analiz edilebilmektedir (Cramer ve Howitt, 2004, s. 89). Kişilerin tutumlarını nicel verilerle ayırt etmek, sınıflamak ve yorumlamak daha karmaşık bir süreç ortaya koymaktadır. Likert (1932) "Bir Tutum Ölçüm Tekniğ̣" isimli araştırmasında sosyal tutumun sayısal veriler ile ölçülebilirliği ve bu sayede kişilerin tutumlarının ayırt edilebilirliğine ulaşılabileceğini belirtmiştir. Katılımcıların tutumlarına karşıllık gelen sayısal verileri işaretlemeleri çok daha kolay sınıflandırılan ve ölçülebilen değerlendirme ortaya koymuştur (Likert, 1932, s. 8).

Şirket etik kodlarını yayınladığı metni "Sürdürülebilir büyümenin yolu insan kaynağıdır" mottosu ile duyuran firmanın ilan ettiği on yedi etik koddan her birini şirket çalışanlarının diğer çalışanların tutum ve davranışları açısından 1 (Kesinlikle Katılmıyorum) - 5 (Kesinlikle Katılıyorum) olacak şekilde değerlendirmeleri istenmiştir. Google Forms programı üzerinden hazırlanan anket formu 66 çalsşana eposta ile iletilmiştir. Uygulanan ankete 66 çalışandan 61 kişi katılım sağlamıştır. Ulaşım ve şirket içi hizmet alanında çalışan kişilerin düzenli e-posta kullanımlarının olmaması anakitlenin tamamına ulaşmada engel olarak ortaya çıkmıştır. Çalışanların bazılarının ankete katılmama ya da bazı soruları cevaplamamayı tercih etme nedeni ise çalışanlarca, belirtilen konular hakkında yorum yapmayı kendilerine uygun görmedikleri ve anketin gerçekten anonim olmayacağına karşı duydukları kuşku olarak dile getirilmiştir. Ayrıca ankete katılan 61 kişiden bazıları, sorularda geçen ifadeleri tam anlayamadıkları için cevap veremediklerini de belirtmişlerdir. Bu durum anket formunu hazırlama sürecinde firma bünyesinde ilan edilen şirket etik kodlarının kalıp halinde kullanılmış olması firmanın etik kod hazırlama sürecinde şirket çalışanlarına bütünüyle hitap edemediğini göstermektedir. Her bir soruya katılım oranları sorular için hazırlanan Şekillerde açık olarak belirtilmektedir.

\section{Bulgular}

61 katılımcı tarafindan şirketin belirlenen on yedi etik kodunun her biri likert tipi ölçek ile değerlendirilmiştir. Belirtilen ilk etik kod "yasalara daima uymak" şeklinde belirtilmiştir. Aşağıda yer alan Şekil 1 'de katıllımcilara değerlendirmeleri istenilen ifade ve soruya cevap veren kişi sayısı ve verilen puanların oranları yer almaktadır. 


\section{Yasalara daima uyarlar}

61 responses

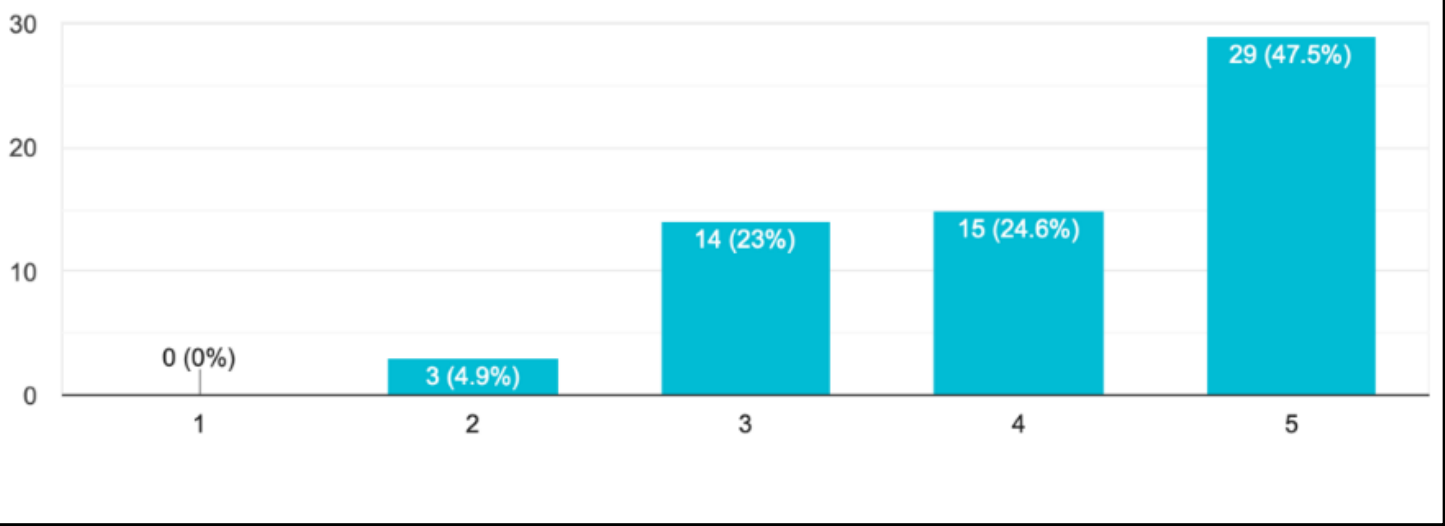

Şekil 1. Şirket Callşanlarn Yasalara Daima Uyarlar

Șirket çalıșanları \%47.5 oranında çalıșma arkadașlarının yasalara daima uyduğunu dile getirmiștir. Bu oran1 \%24.5 oranla "4-katlliyorum" ve \%23 oran ile "3-ne katllyorum ne katilmiyorum" cevab1 takip etmektedir. "Kesinlikle katılmıyorum” yönünde cevap olmaması sevindiricidir.

Şirket etik kodlarında ikinci sırada yer alan şirket çalş̧anları temel ahlaki ve insani değerler çerçevesinde görevlerini yerine getirirler ifadesi hakkında katılımcıların tamamı görüş bildirmişlerdir. 61 katılımcıdan \%41’i çalışma arkadaşlarının ahlaki ve insanı değerler çerçevesinde görevlerini kesinlikle yerine getirdiklerini belirtmiştir. Katılımcıların \%31.1'i de yukarıda belirtilen ifadeye "4-katıllyorum" diyerek şirket çalışanlarının bu konuda ki hassasiyetini ortaya koymuşlardır.

\section{Temel ahlaki ve insani değerler çerçevesinde görevlerini yerine getirirler}

61 responses

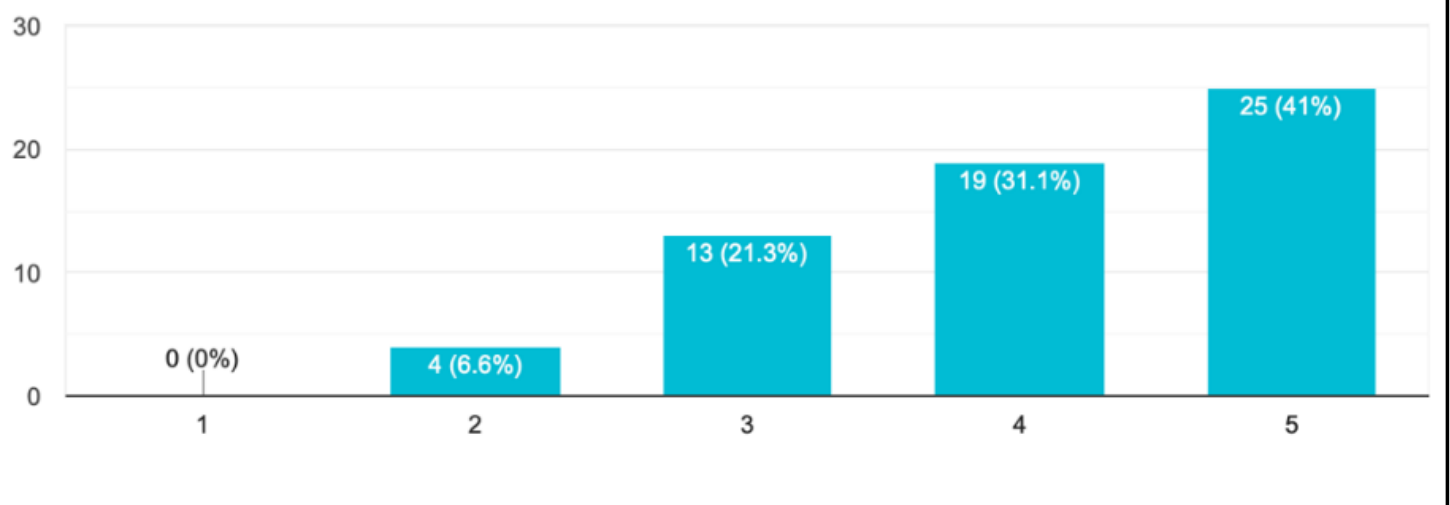

Şekil 2. Şirket Callşanlar Temel Ablaki ve İnsani Değerler Çerçevesinde Görevlerini Yerine Getirirler

Şirket çalışanları tüm ilişkilerinde karşılıklı yarar sağlamak amacıyla hakkaniyetli, iyi niyetli, anlayışlı ve saygılı davranırlar ifadesine verilen cevaplara baktı̆̆ımızda, daha şirket içindeki ilişkiler odaklı bir ifade olarak bu soruya verilen cevaplar çarpıcıdır. 


\section{Tüm ilişkilerinde karşılıklı yarar sağlamak amacıyla hakkaniyetli, iyi niyetli, anlayışlı ve saygılı davranırlar.}

61 responses

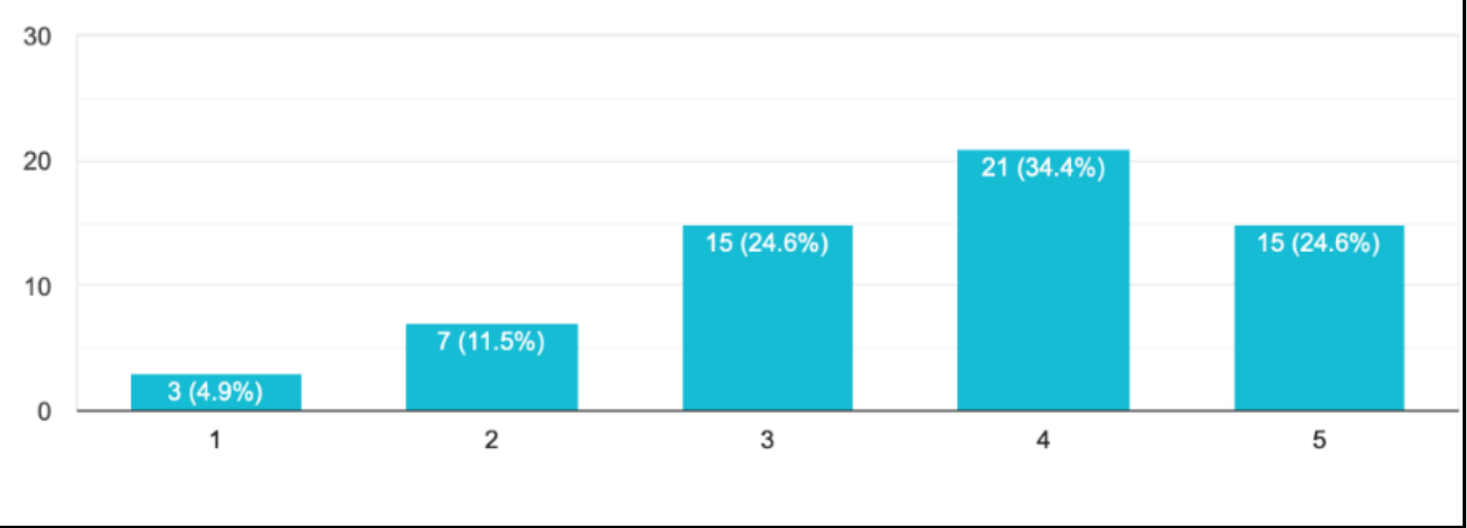

Şekil 3. Şirket Çalışanlar Tüm İlişkilerinde Karşılıkh Yarar Sağlamak. Amacıyla Hakekaniyetli, İyi Niyetli, Anlayışh ve Saygil Davranirlar

Düşük bir oran olsa bile \%4.9'luk bir oranlar üç katılımcının yöneltilen bu ifadeye "1-kesinlikle katılmıyorum" dediği gözlenmektedir. "2-katılmıyorum" seçeneğinin de \%11.5 oranında tercih edilmesi bu konuda şirket çalışanları arasında bir şüphe duygusu olduğunu ortaya koymaktadır. Her ne kadar \%24.6 gibi güçlü bir orana sahip olsa da "5-kesinlikle katıliyorum” cevabinın daha önceki sorulara nazaran daha düşük bir oran ile tercih edildiği ortadadır. Benzer şekilde \%24.6 yüzdesi olan bir diğer seçenek ise ortalama bir ifade olarak ele alına bilecek olan "3-ne katılıyorum ne kat1lmiyorum" ifadesidir.

60 Katılımcının cevaplandırdı̆̆ı şirket çalışanları her ne amaçla olursa olsun kişi ve kuruluşlardan hiçbir şekilde haksız kazanç sağlamazlar ifadesine verilen cevaplar Şekil 4 de yer almaktadır.

Her ne amaçla olursa olsun kişi ve kuruluşlardan hiçbir şekilde haksız kazanç sağlamazlar.

60 responses

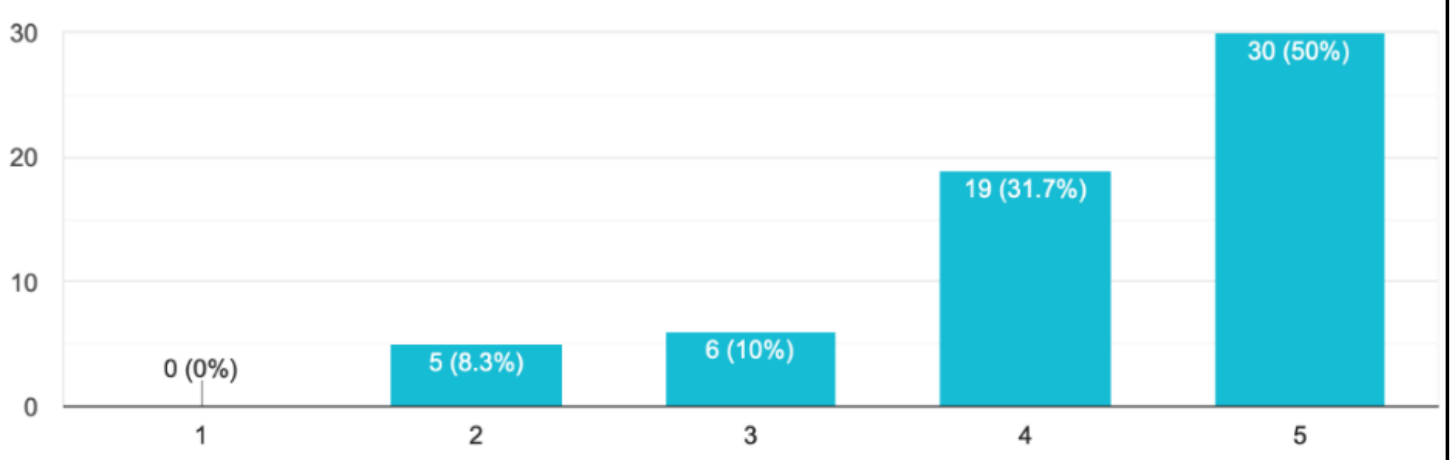

Şekil 4. Şirket Çalışanlar Her Ne Amaçla Olursa Olsun Kişi ve Kuruluşlardan Hiçbir Şekilde Haksız Kaz̧anç Sağlamazlar

$\mathrm{Bu}$ ifadeye yönelik verilen cevaplar incelendiğinde \%50’lik bir oran ile " 5 -kesinlikle katıllyorum" seçeneğinin en yüksek oran ile başı çektiği görülmektedir. Bu sonuç da hem çalışanlar hem de işletme açısından sevindiricidir.

Ankette yer alan bir sonraki ifadeye baktı̆̆ımızda şirket çalışanları şirket içerisinde çıkar çatışmasına girmezler ifadesine yönelik verilen cevaplar Şekil 5 de yer almaktadır. 


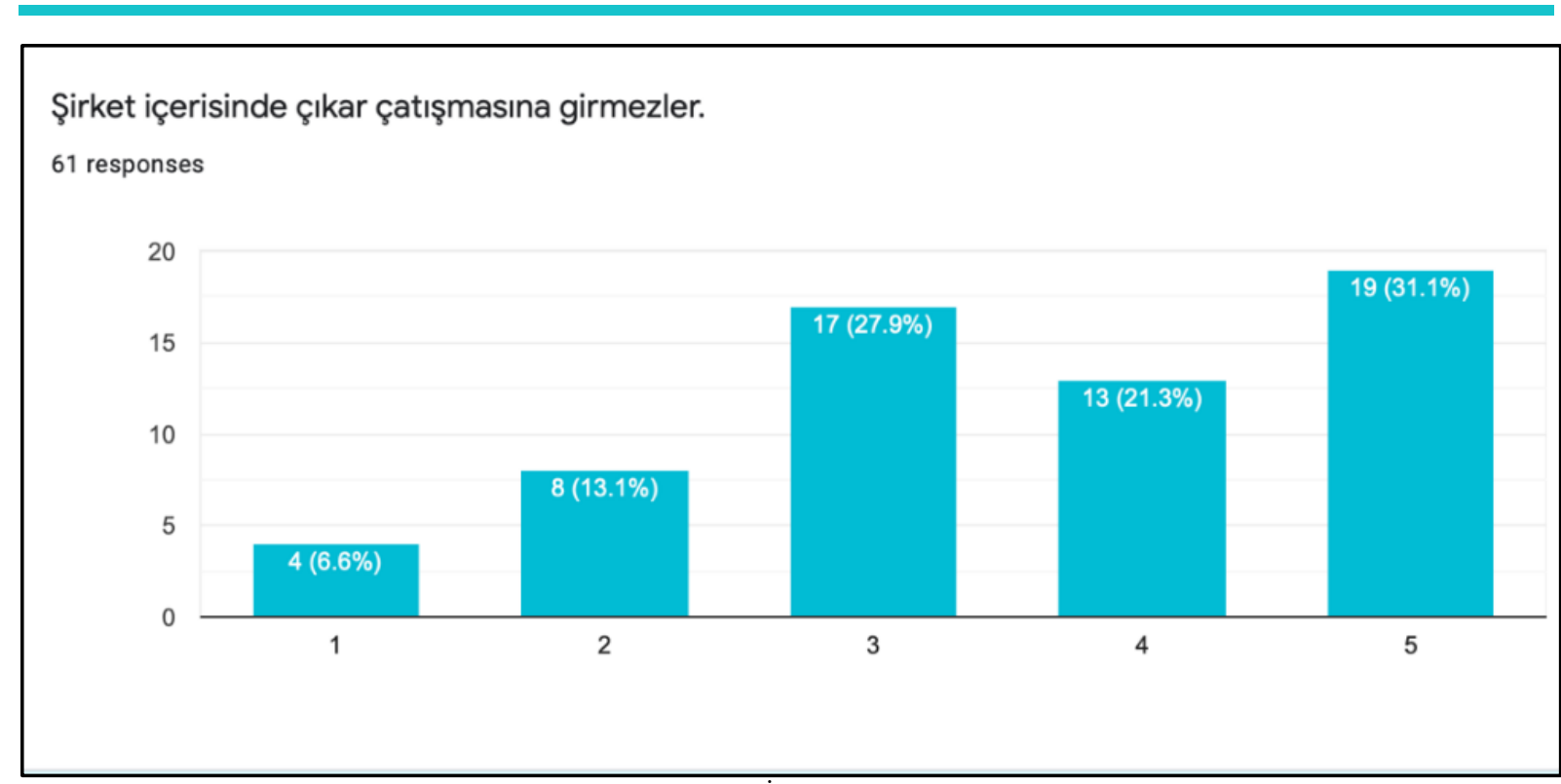

Şekil 5. Şirket Çalışanları Şirket Ị̇erisinde Çıkar Çatıșmasina Girmę̧ler

Daha çok şirket içindeki ilişkilere yönelik olan "şirket çalışanları şirket içerisinde çıkar çatışmasına girmezler" ifadesine verilen cevaplar incelendiğinde, özellikle "1-kesinlikle katılmıyorum", “2katılmıyorum", “3-ne katıliyorum ne katılmıyorum” ifadelerine önceki sorulara nazaran daha yüksek cevapların verildiği gözlenmektedir. Bu üç ifadeye verilen cevapların yüzdesini topladığımızda \%47.6 gibi yüksek bir oranla şirket çalışanlarının diğer çalışma arkadaşlarının şirket içerisinde çıkar çatışmasına girebileceğini belirttiği dikkat çekicidir.

Şekil 6'da yer alan ifadeye bakıldığında bu ifadenin de daha çok şirket içi ilişkileri ele alan bir ifade olduğu çok açıktır.

\section{İş yerinde statüyü, bireysel gücü( unvan, fiziksel, kişisel, yaş) ya da kolektif gücü (sayı fazlalığından kaynaklanan güç) kötüye kullanmazlar.}

60 responses

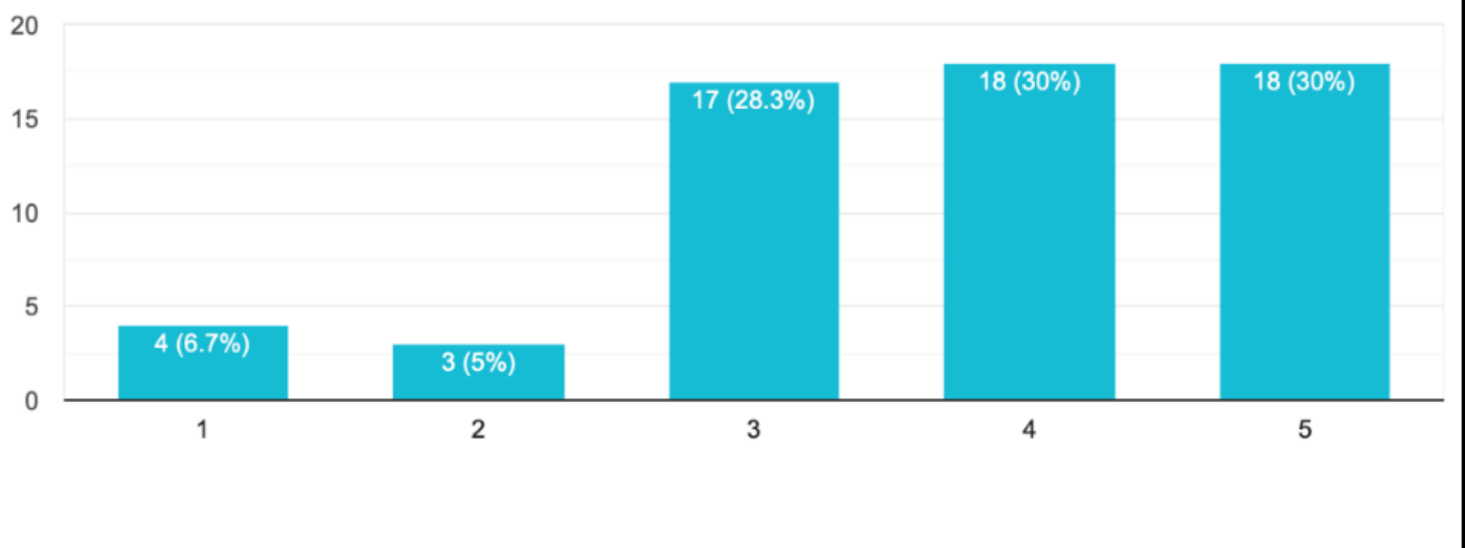

Şekil 6. Şirket Calşanlarnnn Calışma Arkadaşlar İ̧in İş Yerinde Statüyü, Bireysel Gücü ya da Kolektif Gücü Kötüye Kullanmaəlar

Bu soruya verilen cevapta şirket çalışanlarının çalışma arkadaşları için iş yerinde statüyü, bireysel gücü ya da kolektif gücü kötüye kullanmazlar ifadesine \%30'luk oran ile "5-kesinlikle katlliyorum", "4katıllyorum" olmak üzere iki seçenekte yoğunluk olduğunu görmekteyiz. Bu iki seçeneği çok yakın bir fark ile \%28.3 oranı ile "3-ne katıllyorum ne katılmıyorum" seçeneğinin takip ettiği gözlenmektedir.

Çalışmamıza konu olan şirketin 2018 yılında belirlemiş olduğu iş etĭgi kuralları ve uygulama prensiplerine uygun olarak hareket etmeleri, bu kapsamda diğer çalışanların işlerini gereği gibi yerine 
getirmelerini engelleyecek davranışlarda bulunmaları ve iş ahengini bozmamaları konusunu kapsayan ifadeye verilen cevaplar Şekil 7 de yer almaktadır.
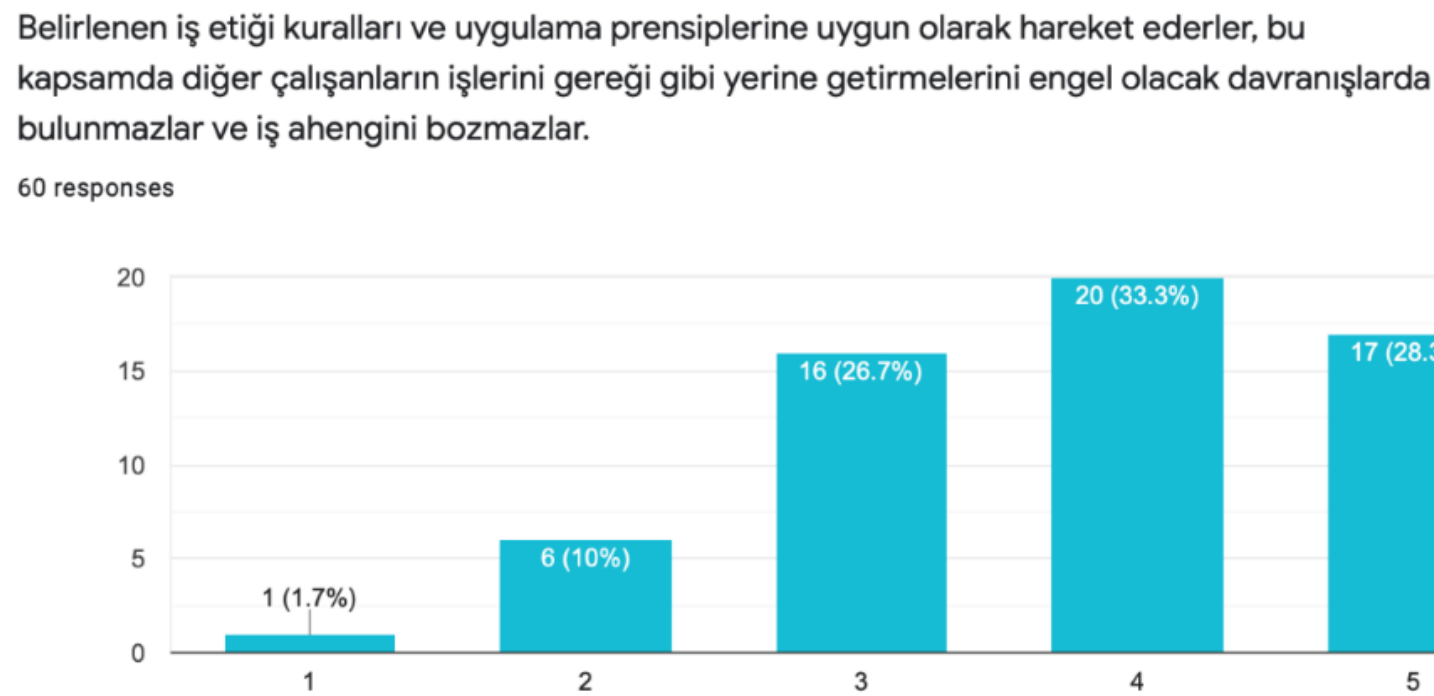

1

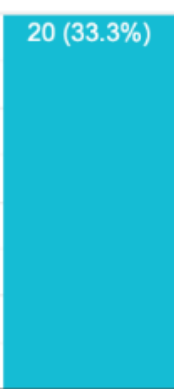

4

\section{$17(28.3 \%)$}

Şekil 7. Sirket Çalşanlar Belirlenen İs Etiği Kurallar ve Uygulama Prensiplerine Uygun Olarak Hareket Ederler, Bu Kapsamda Diğer Calışanlarn Isslerini Gereği Gibi Yerine Getirmelerini Engelleyecek Davramıslarda Bulunmazlar ve $\dot{I}_{s} s$ Ahengini Bozmazlar

Şekil 7'de yer alan ifadeye \%33.3 oranında katılımcının "4-kattlıyorum" cevabını verdiği görülmektedir. \%26.7 oran ile "3- ne katiliyorum ne katılmiyorum" cevab1 ve \%10 oranında "2katılmıyorum" cevaplarının göreli yüksek tercih edilir olması şirket içindeki çalışma ortamının kurulması ve iş uyumunun yansımalarının çok da doğru ortaya konulamadığını göstermektedir.

Şirket etik kodları arasında yer alan bir diğer ifadeye bakıldığında, "şirket çalışanlarının unvan ve yetkiden faydalanarak, kendisi, yakınları veya üçüncü kişiler lehine haksız menfaat sağlamazlar" ifadesine verilen cevaplar Şekil 8'de yer almaktadır.

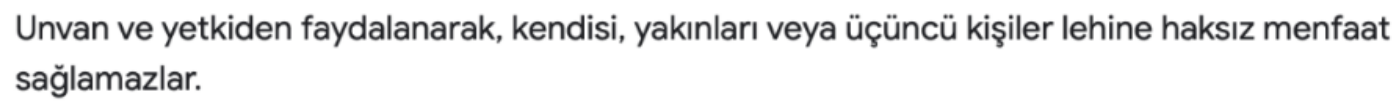

61 responses

30

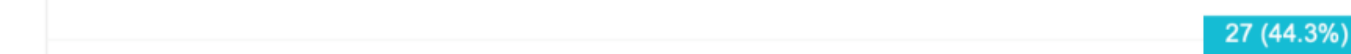

20

10

0

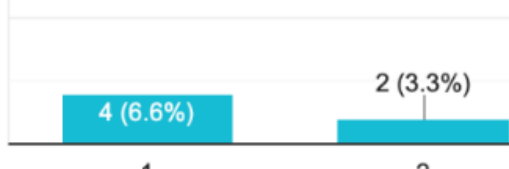

2

4

5

Şekil 8. Şirket Callşanlar Unvan ve Yetkiden Faydalanarak, Kendisi, Yakınlar Veya Üçüncü Kişiler Lehine Haksız. Menfaat Sağlamazlar

Şekil 8'de belirtilen ifade hem şirket içi ilişskileri hem de şirket dışı ilişskileri işaret eden bir yapı ortaya koymasından doğru ele alındığında ifadeyi değerlendiren 61 kişiden \%44.3'unun "5-kesinlikle katılıyorum" cevabının verildiği görülmektedir. Ancak küçük oranlar olmasına karşın \%6.6 "1-kesinlikle katılmıyorum”, 
\%3.3 "2- katılmıorum" ifadelerinin de tercih edilmesi daha önce de ele alındığı gibi, şirket içinde ilişkilerin düzen ve ahenginde ki sorunu dişa vurur şekildedir.

Araştırmaya katılan 61 kişiden 59 kişinin Şekil 9 da yer alan ticari ilişki içinde bulunulan bir başka şirkette yakınlarının pay veya maddi menfaat sahibi olmasının öğrenilmesi durumunda üst amirine bilgi verirler ifadesine cevap verdiği görülmektedir.

\section{Ticari ilişki içinde bulunulan bir başka şirkette yakınlarının pay veya maddi menfaat sahibi olmasının öğrenilmesi durumunda üst amirine bilgi verirler.}

59 responses

30

20

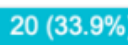

10

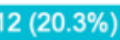

0

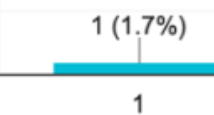

\section{$3(5.1 \%)$}

Şekil 9. Şirket Calışanları Ticari İlişki İçinde Bulunulan Bir Başkea Şirkette Yakınlarmm Pay veya Maddi Menfaat Sahibi Olmasının Ögrenilmesi Durumunda Üst Amirine Bilgi Verirler

Anket her ne kadar kişi bilgisine yer verilmeden gerçekleştirilmiş olsa bile, yapılan bazı geri dönüşler doğrultusunda bazı etik kodların anlaşılmasının zor olduğu ifade edilmiştir. Bu soruya göreli düşük oranda katılım olması ifadenin zor anlaşılır olduğunu düşündürmektedir. Soruyu cevaplandıran 59 kişiden \%39 oranında "5- kesinlikle kattlıyorum" şeklinde ifadeyi cevaplandırdığı gözlenmektedir. Şekil 10'da yer alan ifadeye baktı̆̆ımızda da bu ifadeye de 59 katılımcı cevap vermiştir. Bu ifadenin uzunluğunun ifadenin anlaşılmasını güçleştirdiği düşünülmektedir.

Yeni geliştirilen ürün, süreç ve yazılımların fikri mülkiyet haklarını teminat altına alabilmek için yasal olarak işlemlerin zamanında başlatımasını ve tamamlanmasını sağlamak, bu tür buluş ve bilgilerin yazııı onay alınmaksızın üçüncü kişilerle paylaşıımasını önlerler.

59 responses

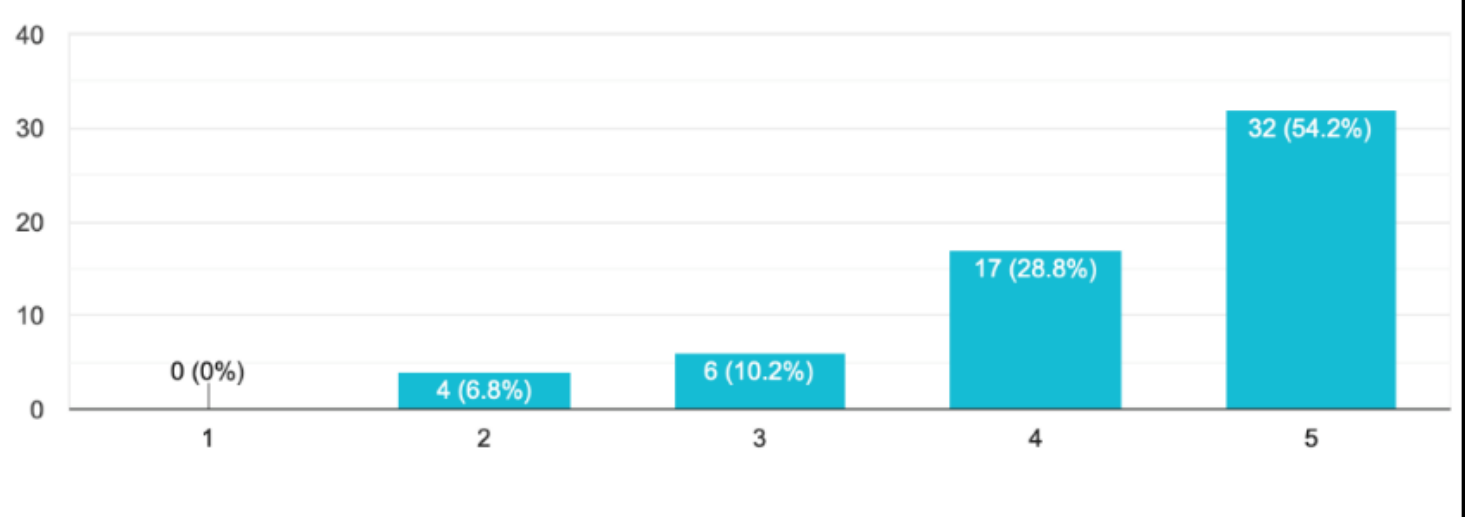

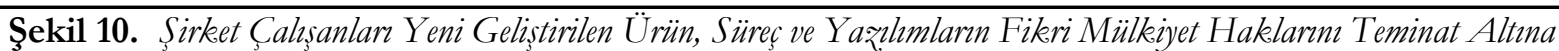
Alabilmek İ̧in Yasal Olarak Ișslemlerin Zamannda Başlatılmasın ve Tamamlanmasim Sağlarlar, Bu Tür Bulus ve Bilgilerin Yaz̨lı Onay Alnmaksız̨n Ü̧̧̈̈ncü Kişilerle Paylaşılmasım Önlerler 
Şekil 11'de yer alan şirket çalışanları açıkça yetkilendirilmedikçe şirketi taahhüt altında bırakacak bir davranışta, beyanda ya da yazışmada bulunmazlar ifadesi \%63.3 oran ile "5-kesinlikle katılıyorum" cevabı verilmiştir. Bu oran en yüksek oran alan ifadelerden biri olarak karşımıza çıkmaktadır.

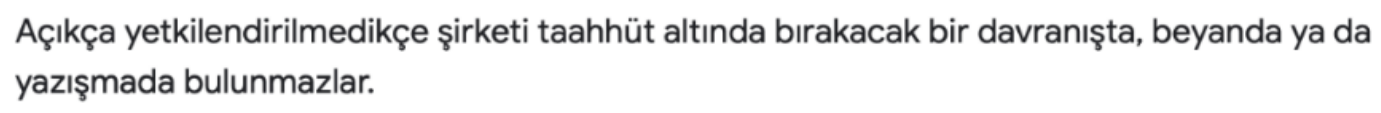

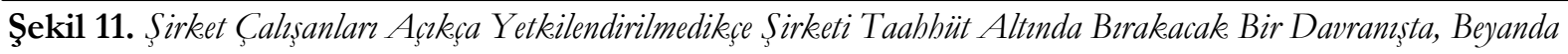
ya da Yaz̧șada Bulunmazlar

Bu ifadeye "4- kat1liyorum" cevabı \%30 gibi bir oran ile verilmiştir. "5- kesin kat1liyorum" cevabın aldığı \%63.3 oran ile kıyaslandığında en yakın seçenek ile arasında oldukça yüksek bir fark olduğu gözlenmektedir.

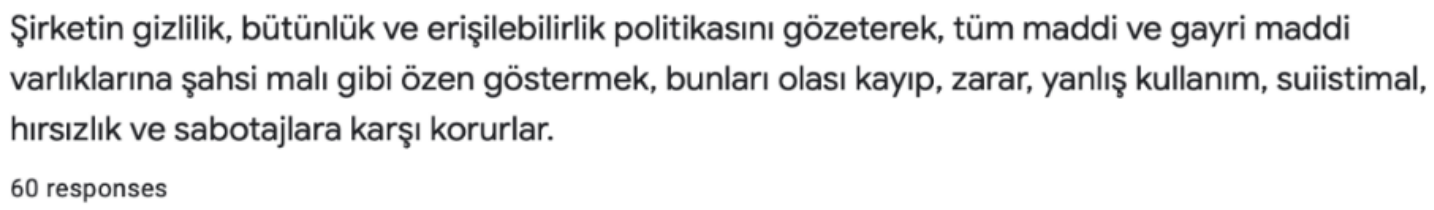

1

Şekil 12. Şirket Calşsanlar Şirketin Giłllilik, Bütünlük ve Erişilebilirlik Politikasım Gözeterek, Tüm Maddi ve Gayri Maddi Varlıklarna Şabsi Malı Gibi Özen Gösterirler, Bunlar Olası Kayı, Zarar, Yanlıs Kullanım, Süistimal, Hirsızllk ve Sabotajlara Karşı Korurlar

Yukarıda Şekil'12 de yer alan oranlara bakıldığında \%58.3 "5-kesinlikle katılıyorum" cevabının en yüksek orana sahip olduğu gözlenmektedir. Bir sonraki ifadede ise (Şekil 14) şirket çalısanlarının topluluğa ait her türlü fikri ve sınai mülkiyet haklarına ilişkin gizli bilgilerin üçüncü kişiler ile paylaşılmasının gerektiği durumlarda haklarımızın korunması için gerekli tedbirleri ilgili prosedürlere uygun olarak alırlar önermesine $\% 56.7$ oran ile " 5 - kesinlikle katıllyorum” cevabının verildiğgi görülmüştür. 


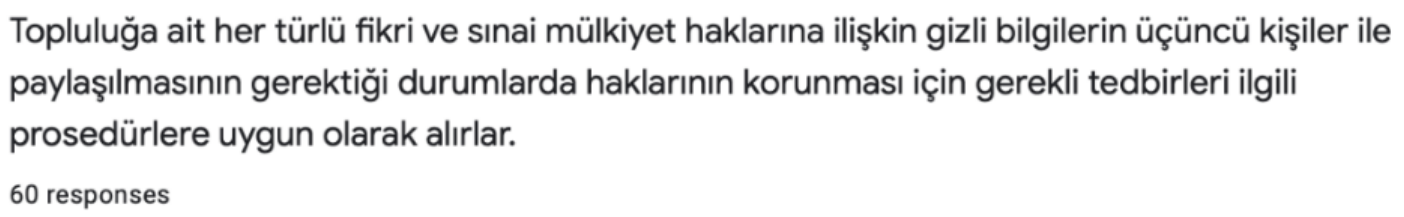

60 responses

40

30

20

0

0

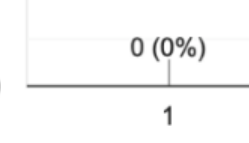

1

2

$8(13.3 \%)$

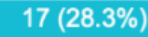

\section{$17(28.3 \%)$}

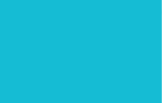

4

5

Şekil 13. Şirket Çalşanlarmm Toplulüga Ait Her Türlü Fikeri ve Smai Mülkiyet Haklarna Ilişkin Gižli Bilgilerin Ü̧üncü Kişiler İle Paylaşılmasının Gerektiği Durumlarda Haklarmıı̨n Korunması İ̧in Gerekli Tedbirleri İlgili Prosedïrlere Uygun Olarak Alirlar

Şekil 14'de yer alan ifade ve cevapların oranlarına bakıldığında gene \%55.7 gibi yüksek bir oranla " 5 kesinlikle katılıyorum" cevabın tercih edildiği gözlenmektedir. Ayrıca bu ifadeye 61 kişinin de cevap vermiş olması kısa ve net soruların katılımcılar tarafindan daha kolay anlaşıldığını düşündürmektedir.

Tüm kayıtların yasal süresinde sağlıklı bir şekilde tutulmasını ve arşivlenmesini sağlarlar.

61 responses

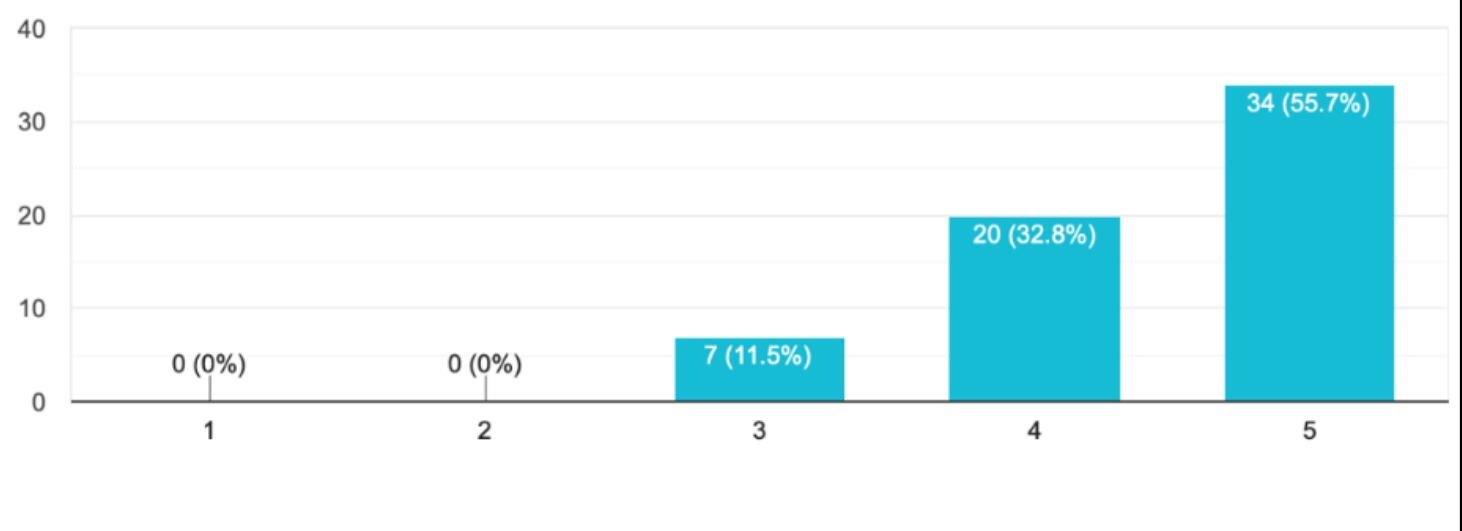

Şekil 14. Şirket Çalışanlar Tüm Kayıtlarn Yasal Süresinde Sağlıkh Bir Şekilde Tutulmasını ve Arşivlenmesini Sağlarlar

Aşağıda Şekil 15 de yer alan ifadeye 59 katılımcının cevap verdiği görülmektedir. Kısa ve net bir ifade olmasına karşın içerik olarak daha üst yönetimi ilgilendiren bir tutum taşıdığı belirtilen bu soruya göreli alt pozisyonlarda çalışan bireylerin "biz gizli kategorisine giren bilgiler ile ilgili pek fazla şey bilmeyiz" tarzında geri dönüşler olduğu belirlenmiştir. 


\section{Üçüncü kişilerden gelen şirket için gizli kategorisine giren bilgi taleplerini, üst yönetim onayı olmadan cevaplamazlar.}

59 responses

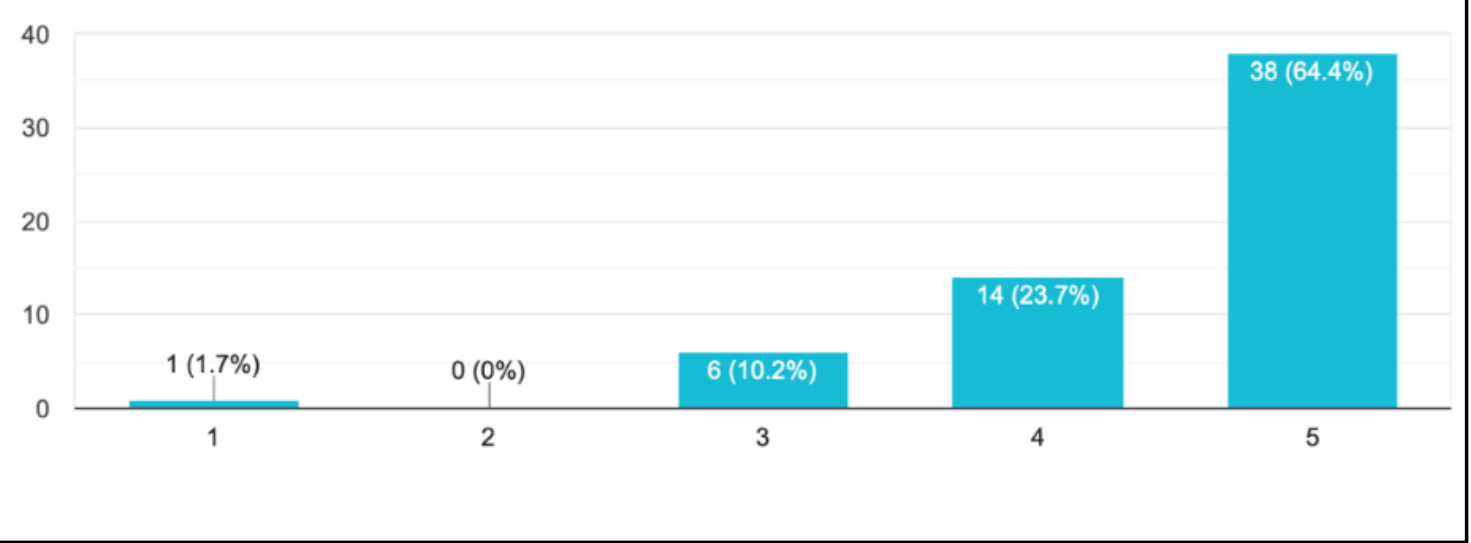

Şekil 15. Şirket Callşanlar Ü̧̧üncü Kişilerden Gelen Şirket İçin Gið̨li Kategorisine Giren Bilgi Taleplerini, Üst Yönetim Onayz Olmadan Cevaplamazlar

Şirket etik kodları arasında yer alan şirket çalışanları şirketin açıkladığı beyan ve sunduğu raporların gerçeğe uygun olması için gerekli şeffaflığ ve titizliği gösterirler ifadesine baktı̆̆ıııda \%59 oran ile 61 katılımcıdan 36sinin "5-kesinlikle katıllyorum” cevabını verdiği gözlenmektedir.

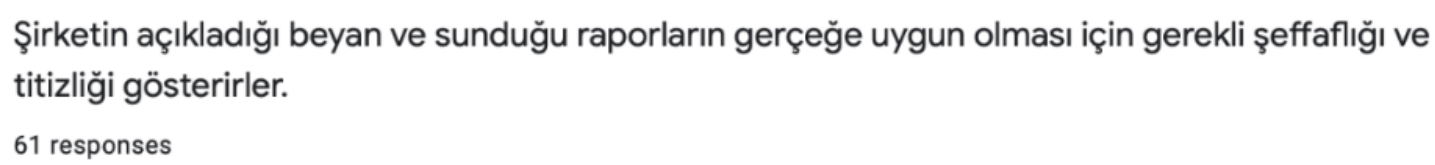

61 responses

$$
40
$$$$
30
$$

20 10

(1)

0

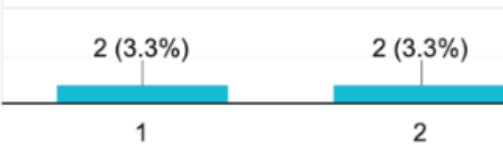

2

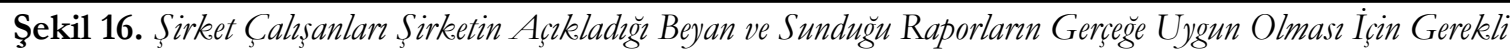
Şeffafliğ ve Titizlĭgi Gösterirler

2018 y1lında beyan edilen son şirket etik koduna bakıldığında; şirket çalışanları olası terör, doğal afet ve art niyetli girişimlere karşı şirket çalışanlarını, bilgi ve bilgi sistemlerini ve idari tesislerin korunması için gerekli tedbirleri alırlar ve iletişimini sağlarlar ifadesine \%60 "5-kesinlikle katıllyorum" şeklinde cevap vermiştir. Bu orana kattlıyorum ifadesine verilen $\% 28.3$ oran da eklendiğinde $\% 88.3$ gibi oldukça yüksek bir oranla katılmış olmaları işletmenin güvenliğinin sağlanmasının ve iletişime önem verdiklerinin göstergesidir. 
Olası terör, doğal afet ve art niyetli girişimlere karşı şirket çalışanlarını, bilgi ve bilgi sistemlerini ve idari tesislerin korunması için gerekli tedbirleri almak ve iletişimini sağlarlar.

60 responses

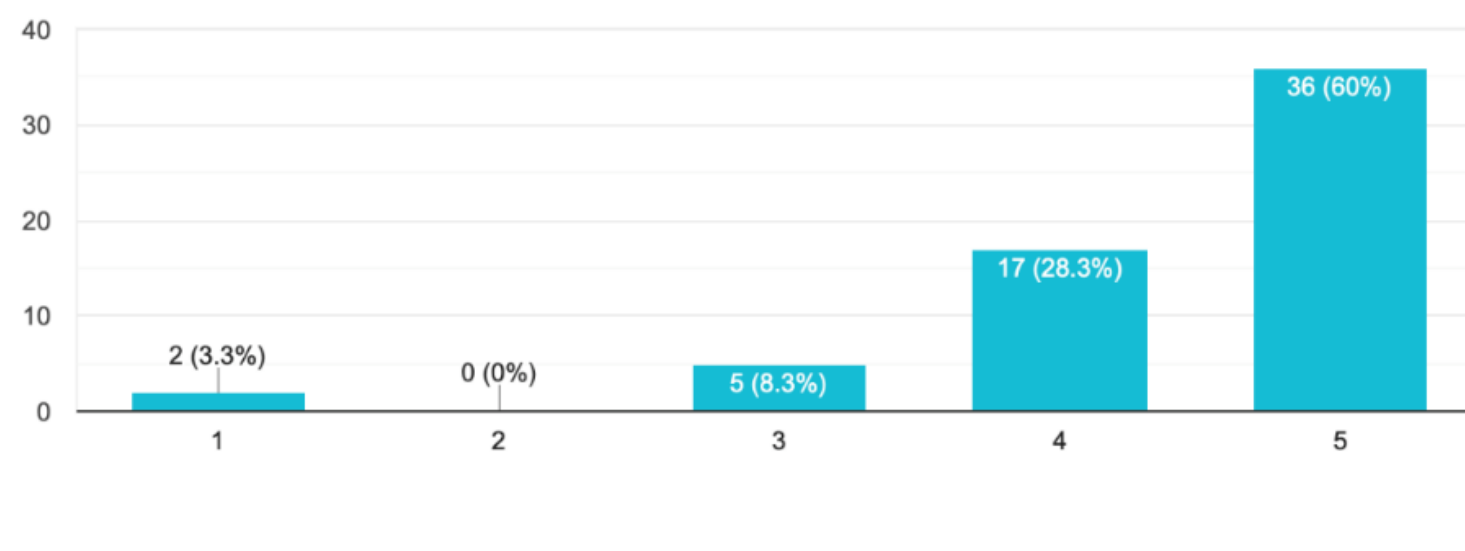

Şekil 17. Şirket Calışanları Olası Terör, Doğal Afet ve Art Niyetli Girişimlere Karşı Şirket Calışanlarmı, Bilgi ve Bilgi Sistemlerini ve İdari Tesislerin Korunması İçin Gerekli Tedbirleri Alırlar ve İletişimini Sağlarlar

Yapılan bu çalışmada da görüldüğ̈ gibi meslek etiği, bir yandan çalışanların hem kendini geliştirmesinde hem de aynı meslekte çalışan diğer iş görenlerle ilişkisinde çok önemli bir yer tutmaktadır. Tip doktorların "Hipokrat Yemini" herkes tarafindan bilinen en eski meslek etiğidir. Avrupa'da pek çok ülke tarafından kullanılan meslek etiği uygulaması Türkiye'de de çeşitli meslek alanlarında kullanılmaktadır. Çalışmamıza konu olan işletme 2018 yılından bu yana da etik Kod uygulamasında şirket kültürüne aykırı olması ya da var olan uygulamalarla ters düşmesi nedeniyle uygulanamayacağı önceden bilinen kurallara yer vermemiş ve en üst düzey yönetim tarafından desteklenmiş, kuralların istisna kabul etmediğini ve tüm çalışanlara ayırım gözetmeksizin eşit olarak uygulanacağını belirtmiştir.

\section{Tartışma, Sonuç ve Öneriler}

Bu çalışmada etik kodlar hem oluşturulma şekilleri hem de şirket çalışanları açısından nasıl değerlendirildikleri üzerinden irdelenmiştir. TÜSİAD’’n 2005 de yayımladığı etik kod ilkelerinden ilk sırada olan "Yalın bir dil kullanılarak hazırlanmalıdır, amaçlar açıkça ifade edilmelidir" şeklindeki açıklamasını destekler şekilde çalışanlar tarafindan açık ve net olarak ifade edilen etik kodların anlaşılırlığı daha yüksek olduğu düşünülmektedir. Uygulanan anket çalışmasında da kısa ve net ifadelerin katılımcıların tamamı tarafından işaretlenme oranın yüksekliği bu durumu destekler niteliktedir.

Şirket çalışanları şirketin açıkladığı beyan ve sunduğu raporların gerçeğe uygun olması için gerekli şeffaflığı ve titizliği gösterirler ifadesine verilen cevaplarda "katıllyorum" ve "kesinlikle katıliyorum" şeklindeki cevapların oranının toplamının \%83 olması çalışanların gerçeklik ve şeffaflığa çok önem verdiklerini göstermektedir. Diğer yandan şirket çalışanları olası terör, doğal afet ve art niyetli girişimlere karşı şirket çalş̧anlarını, bilgi ve bilgi sistemlerini ve idari tesislerin korunması için gerekli tedbirleri alırlar ve iletişimini sağlarlar ifadesine "katıllyorum" ve "kesinlikle katıllyorum" şeklinde verilen cevapların oranın \%88.3 gibi yüksek bir oran olması alışanların bu tür eylemlere karşı kendilerinin güvenliğine şirket tarafindan önem verildiği şeklinde düşündüklerini göstermektedir.

Firma dışı ilişkileri ele alan sorulara "5-kesinlikle katıllyorum", "4-katıllyorum" cevabını veren katılımcı oranları oldukça yüksektir. Firma dışı ilişkiler ile ilgili ifadelerde çalışanların diğer çalışanlar ile ilgili görüşleri çok daha net ve kesin olarak ele alınmaktadır. Ayrıca şirketin kendi içindeki ilişkileri üzerine olan ifadelerin diğer ifadelere verilen cevaplara nazaran "1- kesinlikle katılmiyorum", "2- katılmıyorum" cevabını daha yüksek oranda aldığı gözlenmektedir. Bu durum çalışanların firma içi ilişkilerde çalsşanların birbirine karşı daha güvensiz bir tutum sahibi olduklarını ortaya koyarken firma dışı ilişkilerde çalışma arkadaşlarına güvenlerinin daha yüksek olduğunu göstermektedir. Böylesi bir sonuç çalışmaya konu olan şirketin firma içi ilişkiler göz önüne alındığında çok daha özenli olması gerektiğini ortaya koymaktadır. 
Bu çalışma kapsamında bir firmanın belirlemiş olduğu on yedi etik kod ele alınmıştır. Uygulanan anket sonuçları ve değerlendirmeler şirket yönetimine iletildiğinde şirketin etik kodların geliştirilmesi ve uygulanması konusunda planlamaları aşağıda yer almaktadır;

- Şirket içinde yapılmakta olan oryantasyon sunumlarında etik ve etik kodlar konusunu detaylandirmak

- Şirkete yeni başlayan çalışanların şirket etik kodları hakkında detaylı bilgilendirilmesi, şirket etik kodlarının yazılı olarak bildirilmesi

- Araştırma sonucunda elde edilen bazı bulguların şirket içinde paylaşılması

- Etik kodların yaşayan bir olgu olarak ele alınarak, takip edilmesi, güncellenmesi ve geliştirilmesi için sürekli değerlendirmeler yapılması

Her işletme kendine özgü kültürü ile farklllıklar gösterse de iş etiği, müşteri memnuniyeti gibi kavramlar tüm işletmeler için genel ilkelerdir. Bu nedenle rekabet ve global bir işletme olabilmek ve sorunları daha rasyonel çözebilmek için etik kodların en önemli araç olduğu düşüncesi yaygınlaştırılmalıdır. Her firmanın kendine özgü örgüt kültürü, normları, değerleri, çevresi gibi faktörleri göz önünde bulundurarak etik kodları belirlemesi gerekmektedir. Diğer yandan etik kodlar şirketin tüm paydaşlarının benzer ve kabul gören bir etik anlayışına sahip olmasını sağlar. Burada unutulmaması gereken şey etik kodların canlı birer norm ve değerler topluluğu olduğu ve zaman zaman ortaya çıkan ihtiyaçlara göre şekil değişikliğinin sağlandığı sürece gerçek anlamda yararlı olacağının unutulmaması gerektiğidir. Etik Kod'un uygulamaya konulmasından itibaren, özellikle üst yönetim, etik kodla belirlenen tüm kurallara uyarak, çalışanlarına örnek olmalıdır. Ahlaklı olmakla başarılı olma arasında pozitif yönlü bir ilişki kurabilen ve Etik Kod'a sahip olan ve bu kuralların etkin bir şekilde uygulandığı şirketlerin iş hayatında daha başarıll, rekabet edebilen ve kalıcı olduğu da bir gerçektir. Ayrıca bir firma belirlediği etik kodların geçerliliği ve anlaşılırlığını da belirli periyotlar dahilinde ele almalı ve yaşayan bir kavram olarak etik kodların güncelliğini gözetmelidir. Bu kapsamda çalışmamıza konu olan firmaya, uygulanan anket sonuçlarına verilen cevaplardan yola çıkarak 2018 yılında yayınladığı şirket etik kodlarının yeterince anlaşılır olmadığını iletilmiştir. Firma bu konuda çalışmalar yaparak şirket etik kodları üzerinden güncellemeler yapılacağını belirtmiştir. Bu ve benzeri çalışmaların yapılması hem etik hakkında literatürün zenginleşmesine katkı sağlamakta hem de işletmeler açısından etik kodların oluşturulması ve uygulanması açısından ilerleyici bir adım ortaya koymaktadır.

\section{Etik Beyan}

"Etik Kodlarn Örgütsel Açıdan Değerlendirilmesi” başlıklı çalışmanın yazım sürecinde bilimsel kurallara, etik ve alıntı kurallarına uyulmuş; toplanan veriler üzerinde herhangi bir tahrifat yapılmamış ve bu çalışma herhangi başka bir akademik yayın ortamına değerlendirme için gönderilmemiştir. Bu çalışma, Kırıkkale Üniversitesi Sosyal ve Beşeri Bilimler Araştırmaları Etik Kurulu'nun 18/02/2021 Karar Tarihi ile Oturum No: 02 Karar: 15 sayılı izin ile Etik ilkelere uygun olduğuna karar verilmiştir.

\section{Kaynakça}

Bauman, Z. (1998). Postmodern etike (Çev: A. Türker). Ayrıntı Yayınları, İstanbul.

Bayrak Kök, S. (2006). Organizasyonel kurumsallaşmada bir değer boyutu: İş ahlakının kurumsallaşması. $\dot{I}_{s}$, Güc Endüstri İlişkileri ve Insan Kaynaklar Dergisi, 8(1),

Cramer, D. ve Howitt, D.L. (2004). The SAGE dictionary of statistics: A practical resource for students in the social sciences. Londra: SAGE.

Çabuk, S. ve Şengül, S. (2005). İşletme yöneticilerinin mesleki değerlerinin ve demografik özelliklerinin işletme etiği üzerindeki etkisi: Türkiye'de büyük ölçekli sanayi işletmeleri üzerine bir uygulama. Cukurova Üniversitesi Sosyal Bilimler Enstitüsü Dergisi (e-dergi), 14(1), 171-180.

Doğan, N. (2009). İş etiği ve işletmelerde etik çöküş. SÜ İIBF Sosyal ve Ekonomik. Araştrmalar Dergisi, 8(16), $179-200$.

Ersel, H. (1998). Aracılarn Kendi $\dot{I}_{c} \dot{I}_{s}$ sleyişinde ve Müsterileri İle Olan İlişkilerinde Etike Değerler. Türk Sermaye Piyasasında Etik Değerler ve İş Adabına İlişkin Çalışma Kuralları İstanbul: İstanbul Menkul Kıymetler Borsası Acar Matbaacilik A.Ş,

Harlak, H. (2003). Temel iletişim becerileri. Aydın: ADÜ Yayınları.

Kuçurad1, İ. (2006). Etik. Ankara: Türkiye Felsefe Kurumu.

Likert, R. (1932). A technique for the measurement of attitudes. Archives of Psychology, 22, 5-55

Özdoğan, F. B. (2007). Pazarlamada tüketim ve tüketici ablakı. Ankara: Siyasal Kitabevi.

Öztürk, N. K. (2001). Kamu ve özel yönetim etiği: Benzerlikler ve farklılıklar. Amme İdare Dergisi, 34(1), 2-8. 
Öztürk, N. K. (1998). Kamu yöneticilerinin kararlarında etik değer. Amme İdare Dergisi, 31(2), 15-26.

Pater, A. ve Gils, A. V. (2003). Stimulating ethical decision-making in a business context: Effects of ethical and professional codes. European Management Journal, 21(6), 762-772.

Peppas, S. (2002). Attitudes toward business ethics: Where east doesn't meet west. Cross Cultural Management: An International Journal, 9(4), 42-59.

Plant, J. F. (2001). Codes of ethics: Handbook of aministrative ethics (Edt: T. L. Cooper). New York: Dekker.

Russ-Eft, D. ve Hatcher, T. (2003). The issues of international value and beliefs: The debate for a global hrd code of ethics. Advences in Developing Human Resources, 5(3), 296-307.

Signh, C. ve Parasad, M. (2017). Code of ethics in an organisation. International Journal of Application or Innovation in Engineering \& Management, 6(5), 138-142.

Svensson, G. ve Wood, G. (2004). Codes of ethics best practice in the swedish public sector: a Pubsec - Scale. The International Journal of Public Sector Management, 17(2), 178-195.

TEDMER (2007). http:/ /www.tedmer.org.tr/pps/etikbarometre.pps erişim tarihi 23.05.2007

Tevruz, S. (2007). Etik yaklaşımlar ve iș ablake, iş hayatında etik (Edt: S. Tevruz). İstanbul: Beta Yayınları.

Torlak, Ö. (2006). Pazarlama ablakı. İstanbul: Beta Basım A.Ş.

TÜSİAD (2005). Devlette etikten etik devlete: Kamu yönetiminde etik kavramsal çerçeve. İstanbul: TÜSİAD-T/2005 - 11/412

Valentine, S. ve Fleischman, G. (2002). Ethics codes and professionals: Tolerance of societal diversity. Journal of Business Ethic, 40(4), 301-312.

Y1lmaz, G. (2007). Akademisyenlik mesleğine yönelik etik kodlarn gelistirilmesine ilişkin görgül bir araştırma (Yüksek Lisans Tezi). Manisa Celal Bayar Üniversitesi Sosyal Bilimler Enstitüsü, Manisa.

Yüksel, M. (2015). Etik kodlar, ahlak ve hukuk. Hacettepe HFD, 5(1), 1-26.

https://home.kpmg/tr/tr/home/gorusler/2017/03/sirketlerin-olmazsa-olmazi-etik-kod.html (Erişim Tarihi: 18.12.2020)

\section{EXTENDED ABSTRACT}

In this study, the understandability and enforcement of Code of Ethics is evaluated through a company's real world experience of their employees. The purpose of this assessment is to reveal the contributions and importance of ethical codes for company as a living and developing phenomenon; and also as a concept to understand how a company acts within the scope of ethical codes, increasingly wide spreading as real life implementations for companies today. Ethics and morality, which rooted as old as the history of humanity, are among the words frequently encountered at daily life as oral or written forms. These words have been studied and discussed by many disciplines, primarily philosophy, sociology and law however business and technology also joins to them. And definitely discussion will be continued. In its simplest form, ethics is the integrity of human behavior rules those guide human relations and behavior. Individual shapes his life according to these rules. On the other hand, social life is not composed of sharp and discrete structures. It has a structure which includes uncertainties and unpredictably. At this point, there is a need of ethical codes that is pre-defined and suits to the structure. The ethical codes are valid as long as they are claimed by people and the participation of senior management is ensured. In today's business world, where competition is rapidly experienced, businesses apply different methods and techniques to maintain their market shares and to ensure continuity. One of these methods is the use of ethical code that helps to ensure customer reliability and continuity. Ethical codes, on the other hand, include principles to ensure the satisfaction of both internal and external customers. These principles will make important contributions to corporate's institutionalization and to prevent the parties from facing ethical dilemmas in business life. Ethical codes are one of the foundations of the structuring of professions and institutions. Ethical codes guide employees in line with the values and principles specific to the fields of activity of the institutions. However, while ethical codes are considered as the basis of good and correct behavior, the ethical code of the company is also considered as a guide that shows how a company can best fulfill its responsibilities in every sense. So much so that this guide will ensure the correct, efficient and orderly functioning of a company's internal and external relations. However, it is not enough to create ethical codes at once. In an order where change is inevitable, it is necessary to reevaluate the company's ethical codes in the context of their implementation and validity. In other words, ethical codes are a living process which needs to be fed. In this context, a questionnaire was applied with a five-point Likert scale based on the seventeen ethical code principles announced in 2018 by a company. 61 of 66 company employees were participated in this survey conducted via Google forms application. This study aims to examine how the seventeen items of company ethics codes determined at 2018 are perceived and evaluated by company employees two years later, at 2020. As can be seen in this study, occupational ethics has a very important place in both selfdevelopment of employees and their relationship with other employees working in the same profession. 
The "Hippocratic Oath" of medical doctors is the oldest professional ethic known to all. Such old rooted professional ethics practices which are used by many countries in Europe are also used in various professional fields in Turkey. At 2018, the company that is the subject of our study stated that it had not included any codes contradicting with their rules and the company culture and existing practices. It has been supported by the top management, doesn't accept exceptions and has applied equally to all employees without discrimination. Seventeen ethical codes determined by the company are discussed within the scope of this study. When the applied survey's results and evaluations are shared with the company's management team, they have conducted plans about enhancement regarding implementation of ethical codes are as follows;

- To elaborate the concept of ethic and code of ethic in the orientation presentations made within the company

- To announce the ethical codes of the company in written form and informing the new employees about the ethical codes

- Sharing results of the research within the company

- Planning about continued evaluation to follow up, update and improve ethical codes by considering them as a living concept

Although every organization differs with its unique culture, concepts such as business ethics and customer satisfaction are general principles for all businesses. For that reason, the idea that ethical codes are the most important tool should be widespread in order to be a competitive and to be global business player and to solve problems more rationally. Each firm should determine ethical codes by taking into account factors such as organizational culture, norms, values, and environment. On the other hand, ethical codes ensure that all stakeholders of the company have similar and accepted understanding of ethics. What should not be forgotten here is that ethical codes are a living concept of norms and values, and they will be truly beneficial as long as they are adapted to changes according to new needs those may raise from time to time. During implementation of the Code of Ethics, especially behaviors of the senior management should be example to the employees by complying with all the rules determined by the ethical code. It is also a fact that companies those can establish a positive relationship between being ethical and being successful can have long term sustainability. And employees who are effectively take considerations of Code of Ethics can be more successful, competitive and permanent in business life. In addition, a company should consider the validity and comprehensibility of the ethical codes as routine and should observe the actuality of the ethical codes as a living concept. 